\title{
'OUDE GECOULEURDE JAPANSCHE PORCELEINEN VAN DE EERSTE CLASSE' DE KAKIEMON COLLECTIE IN KASTEEL TWICKEL
}

Kasteel Twickel huisvest een buitengewone kunstverzameling, waaronder veel porselein. Het huis kreeg zijn huidige vorm in de $17^{\mathfrak{c}}$ eeuw, toen het verbouwd werd als buitenverblijf voor de Van Wassenaer Obdam familie, naast hun bezittingen aan de Kneuterdijk in Den Haag. Jacob IV van Wassenaer Obdam was een invloedrijke edele met nauwe banden met de stadhouder. Na zijn dood in 1714 ging de Kneuterdijk naar zijn oudste zoon Johan Hendrik, die het liet ombouwen tot een elegant stadspaleis onder leiding van de beroemde architect Daniël Marot. Na zijn dood verviel het aan zijn broer Unico Wilhelm, die nu Twickel en de Kneuterdijk bezat. Unico Wilhelms zonen erfden op hun beurt beide verblijven, maar aangezien zij geen mannelijke erfgenamen nalieten, gingen Twickel en de Kneuterdijk in het begin van de $19^{\mathrm{C}}$ eeuw over op de aangetrouwde Van Heeckeren familie.

Kakiemon was een geliefd verzamelobject aan de Europese hoven. De familie Van Wassenaer was nauw verbonden met het Stadhouderlijk hof en zeker op de hoogte van de porseleinmode. De inventaris van het huis aan de Kneuterdijk, opgemaakt bij het huwelijk van Jacob IV in 1676, laat zien dat er toen een modieuze porseleinopstelling was. Het is duidelijk dat men goed op de hoogte was en dat het Haagse huis als representatief verblijf was ingericht. Dat gold ook voor het nieuwe stadspaleis dat Johan Hendrik liet ontwerpen. Uiteraard moest daar een nieuw, passend interieur in komen en nadat de oude boedel in 1715 geveild was, besteedde Johan Hendrik de rest van zijn leven om de Kneuterdijk in te richten met een indrukwekkende verzameling kunst. Ook op het gebied van porselein liet hij zich niet onbetuigd. In de verzameling nota's die er van hem bewaard zijn gebleven zitten de aanwinsten van 202 stukken porselein, die hij voor in totaal 5.600 gulden verwierf. Een voorbeeld is de aankoop van ' 11 schotels extra oud Japans coeleurd Porcelijn’, vrijwel zeker Kakiemon porselein.

De Kneuterdijk-verzameling werd in 1750 en 1769 in ieder geval deels geveild. De catalogus maakt duidelijk dat de helft van het verkochte Japanse porselein in Kakiemon-stijl was: 'Oude gecouleurde Japansche porceleinen van de eerste classe'. Maar liefst elf bestaande voorstellingen van Kakiemon kunnen uit de beschrijvingen worden afgeleid.

De oorsprong van de huidige Twickel-verzameling van Kakiemon is niet zeker. De Kneuterdijk is ondanks de veilingen een goede kandidaat; we weten dat er ook na de veilingen nog een enorme hoeveelheid porselein in het huis over bleef. Een andere bron is het bezit van Jacoba Elisabeth van Strijen, de vrouw van Carel George, de zoon van Unico Wilhelm. Zij bracht omvangrijke erfenissen mee. In ieder geval kan uit de samenstelling van de Kakiemon-verzameling geconcludeerd worden dat het een oude collectie is $_{9}$ : $56 \mathrm{Am}$ Het bestaat uit sets die in de $17^{e}$ of $18^{e}$ eeuw verzameld moeten zijnia free access 


\section{MODERN KAKIEMON \\ DE KRACHT VAN YOHAKU (LEGE RUIMTE)}

Het moderne Kakiemon dat nu is te zien in het Keramiekmuseum Princessehof, belicht porselein dat wereldwijd meer bekendheid verdient. Het heeft een lange geschiedenis. Volgens een familiedocument vervaardigt de Sakaida familie sinds 1640 porselein met overglazuur kleuren. Het porselein dat zij maakten kenmerkt zich door een melkwitte nigoshide scherf, het gebruik van asymmetrische ontwerpen met ampel gebruik van witte ruimte (yohaku), en overglazuur kleuren in een door rood gedomineerd palet. De Kakiemon-stijl werd erg populair in het Westen, zodat ook andere werkplaatsen in Arita het gingen maken.

$\mathrm{Na}$ de bloeiperiode van 1670 tot $1700 \mathrm{ging}$ het economisch slechter, vanwege de beëindiging van de VOC-bestellingen in 1757 en het verlies van de Nabeshima-clan als opdrachtgevers in de politiek roerige tijden van de late $19^{\text {de }}$ eeuw. De kwaliteit van het porselein was achteruit gegaan en het geheim van het maken van nigoshide porselein verloren. Kakiemon XI ondernam pogingen de stijl en de kwaliteit weer op het oude niveau terug te brengen. Hij spande zich in om de afzet te vergroten en won prijzen op de Wereldtentoonstellingen van 1893 en 94 . Kakiemon XII trachtte de omzet verder te verhogen door met de zakenman Obata Hideyoshi de firma Kakiemon Co. Ltd. op te richten, met gebruik van het vierkante merkteken van Kakiemon (kakufuku). De kwaliteit van het porselein ging echter achteruit en Kakiemon XII verliet het bedrijf in 1928. Zijn stukken van na die datum signeerde hij Kakiemon saku; de financiële situatie bleef precair. In 1939 nam Kakiemon XIII het roer over en voer een andere koers. Met behoud van de traditionele methodes en technieken, bracht hij moderniteit en originaliteit in de stijl, door schetsen naar de natuur te maken, in plaats van te werken met patroonboeken. Ook introduceerde hij bloemmotieven die uitgespaard werden in het wit van het porselein. In 1976 werd nigoshide betiteld als 'belangrijk cultureel erfgoed', en de Kakiemon oven werd officieel verantwoordelijk gemaakt voor het behoud van de traditionele technieken. Kakiemon XIV studeerde Japanse schilderkunst en nam in 1982 de leiding van de oven over. Hij ontwikkelde met succes een frisse, eigen stijl, en heeft sinds 1968 elk jaar zijn werk tentoongesteld. Zijn stukken kenmerken zich door verfijnde ontwerpen met wilde planten en bloemen, die hij naar de natuur schetst. Hij signeert zijn werk niet, in de overtuiging dat de stijl voor zich spreekt. Kakiemon XIV benadrukt de rol van de traditie en die van de ambachtslieden die bij het productieproces betrokken zijn. Voor hem is yohaku meer dan witte ruimte alleen, het is 'de lege ruimte waar een mens zijn hart in kan stoppen'. Terwijl hij zijn persoonlijke stijl verder ontwikkelt en experimenteert met nieuwe kleurschakeringen, hecht hij aan het behoud van het niveau en materiaalgebruik van de traditionele technieken. Zo plantte hij duizend isu bomen om hun schors te kunnen gebruiken voor het bereiden van glazuur. Zijn prestatie om traditie en vernieuwing harmonieus te verenigen werd in 2001 beloond $_{45: 56 \mathrm{Am}}$ met de prestigieuze benoeming tot 'Levende Nationale Schat'. 